\title{
Revisiting nuclear policies under Modi regime: Leadership analysis and repercussions for Pakistan
}

\author{
Meninjau kembali kebijakan nuklir di bawah rezim Modi: Analisis \\ kepemimpinan dan dampaknya bagi Pakistan \\ Muhammad Umer Hayat* \& Aleena Zaid \\ Department of Humanities and Social Sciences, Bahria University Islamabad \\ Address: Shangrilla Road, Sector E-8, Islamabad, Pakistan 44000 \\ E-mail: umerhayat.buic@bahria.edu.pk
}

Article History: Received 5 February 2021; Accepted 8 June 2021; Published Online 22 June 2021

\begin{abstract}
Modi's leadership and governance pattern is a matter of consideration as concerned directly with styles of functioning of his adopted policies, which reflects his undertakings both in the social and political realm. This paper seeks to offer an alternative perspective in the domain of the rising threat of Hinduism, while the consolidation of the political power in India has been raising serious implications for Pakistan, in particular. It highlights the impact of all such harsh realist nuclear policies that may cause more complexities and further deteriorate the region's stability. This study deployed descriptive, analytical, and explanatory research techniques but to great extent, a major part consists of the descriptive study, which will be used when it comes to genesis and existing various scenarios. Findings also substantiate India's intentions and the propaganda waged and all steps keenly targeting Pakistan. Bharatiya Janata Party (BJP) seems to be adopting new realist approaches deeply rooted with that of Kautilya's. Therefore, the paper concludes that the rise of Hindu nationalists gets the support of Rashtriya Swayamsevak Sangh (RSS)-based concept demanding soft measures to lessen the worrisome environment causing by the Modi regime.
\end{abstract}

Keywords: civil-military; Hindutva; leadership; Modi term 2014-2019

\begin{abstract}
Abstrak
Pola kepemimpinan dan pemerintahan Modi menjadi suatu kekhawatiran yang berkaitan langsung dengan gaya kebijakan yang diterapkan, yang mencerminkan usahanya, baik di bidang sosial maupun politik. Tulisan ini berusaha menawarkan alternatif perspektif terkait meningkatnya ancaman Hinduisme, sementara konsolidasi kekuatan politik di India telah menimbulkan implikasi serius, khususnya bagi Pakistan. Artikel ini menyoroti dampak dari seluruh kebijakan nuklir yang kejam namun tetap harus diterima, yang dapat menyebabkan lebih banyak kompleksitas dan semakin memperburuk stabilitas wilayah Pakistan. Penelitian ini dilakukan dengan teknik deskriptif, analitik, dan eksplanatif tetapi sebagian besar menyajikan penelitian deskriptif yang akan digunakan dalam hal genesis dan berbagai skenario yang ada. Temuan juga memperkuat gagasan terkait niat India dan propaganda yang dilancarkan dan semua langkah yang menargetkan Pakistan. Partai Bharatiya Janata (BJP) tampaknya menggunakan pendekatan realis baru yang berakar kuat pada pendekatan Kautilya. Oleh karena itu, artikel ini menyimpulkan bahwa kebangkitan nasionalis Hindu mendapatkan dukungan dari konsep berbasis Rashtriya Swayamsevak Sangh (RSS) yang menuntut dilakukannya tindakan halus untuk mengurangi terciptanya suasana yang mengkhawatirkan yang disebabkan oleh rezim Modi.
\end{abstract}

Kata kunci: sipil-militer; Hindutva; kepemimpinan; masa Modi 2014-2019

\section{Introduction}

In the discipline of international relations, regarding a question on how to examine states behaviour, scholar sees several levels of analysis such as state, system, individual, and organization. To discuss the role of a leader, one may take the individual-level analysis which closely relates to cognitive theories explaining foreign policies by looking at how leaders look at the world and how they perceive things from a global perspective. It includes concepts of perceptions, misperceptions, and ways of communication (Newmann 2020). This type of analysis level is important because it focuses on the individual that goes 
on in shaping foreign policies. Ultimately, all behaviour is a person behaviour who makes decisions, either to make it in favour of war or peace. Before discussing one specific personality of Modi, it is of utmost importance to understand him individually. In this regard, the level of analysis helps as for the reason to know why such decisions are taken. Not only that, but this also depicts the leaderships in terms of what kind of headship can take steps as per people perceptions so that psychological demonstrations support the raised arguments and solve the puzzles.

The power of individuals magnifies when they came to power as they become a leader or a member of large organizations (Umar 2020). The psychological explanation for war thus states that it is all driven by the madness of kings because the common do not go to war and as in the UNESCO preamble, War begins in the minds of men. Not surprising, India's failure towards maintaining its balance in CMR hence requires an urgent need for attention for the reason of its deep concerns with security matters and its relations with other states, particularly the neighbouring country Pakistan. Taking into account the state of India, leaders continuously develop new solutions to the problems with more effective resources to meet growing needs. Varying challenges to economic needs ponders leadership styles.

Now the modern leadership theory recognizes the importance of skills that relates to both emotional and personal factors. In the context of Indian leadership, different views describe that they might see others as ideals or the desired ones. Indian leadership, therefore, shows that balancing is seen as a critical factor. It indicates that pragmatism and jugaad (flexible approach to solving a problem) are of utmost importance elements for taking any advantage. The most significant internal and external cultural aspect consists of the let it be attitude in India's leadership practices (Tripathi et al. 2015).

While discussing the Modi leadership, things make sense in regards to his policies in which he had shown himself as the sovereign in recreating rules. For the reason of his engagements with state beings, many critiques found him as self-obsessed, which the displayed traces according to an Indian writer, Ramchandra Guha, show ego-centricity or self-love. It compels the nation thus to compare him with the American leader in 1932, Franklin D. Roosevelt, who declared about the pledge with the nation and himself to a brand new deal for the people of America. People compare them though he had not mentioned them all in his term. People were habituated to this alphabet soup as the Modi had presented and still been presenting till his Gujrat days. In sum, it holds the dumb down political narrative, however, assuredly forced the opposition to contest on his battle-front (Makhopadhyay 2019).

The scholarly finding shows that India's propaganda is against its neighbouring country, Pakistan. Hence the surgical strikes and all attempts carried out by Modi shows Hindu Nationalism and in all that, the Indian government is at its front. Even so, governing mode has all the power hold over media that can only operate in accordance with instructions given to them by government officials. Moreover, at present, the government does more than making the state secular. The current model of shift highlights a shift towards the rigid ideology of Hindutva. The real picture is opposite to that of so-called liberal's view in which they are demonstrating the state to make it more democratic. In reality, however, it shows the realist postures. By using a soft power plan now to gain regional hegemony, India has been seeking through various ways such as cultural, social, and political, showing the intentions to attain their primary objective (Hashmi et al. 2018).

A previous study by Khan (2020) expressed the main views regarding the nuclear doctrine of India that the shift or any change in it is no secret in their counterforce strategy, thus the policy of No First Use (refer to a pledge or a policy by a nuclear power not to use nuclear weapons as a mean of warfare) neither permanent nor absolute (Sundaram \& Ramana 2018). As India is having First Use, they are trying their best tactics to acquire both soft and hard counterforce capabilities. More than anything else, the alarming factor is not only about destabilising the regional security, but also the somehow terrifying dynamic, presenting the governance mode under rogue and staunch Hindu nationalists. Ironically, although international attention is needed to curb the rising threat, they are ignoring the repercussions of nukes if in case happens. The nuclear-armed tension is at its climax as the statement of their official 
shows that it all will be going to be dependent upon a futuristic environment, which is a veiled threat issued by the defence minister. Therefore, they are playing fire and risking regional stability as the moves indicate the perception of escalation may come true. Thus to sum up fascist Hindu Government under Modi highlights the scary reality to which it acquires global attention before the nuclear holocaust happens (Jaspal 2019).

\section{Research Method}

This research article employed different research techniques which included descriptive, explanatory, and analytical to analyse the subject matter. The study was descriptive and it covered the various dimensions and scenarios of the study. The major purpose of this research methodology was to locate the authentic explanatory data that support the aim of this study, in addition to divulging the factors along with original perspectives covering the whole research of this article. Moreover, the analytical research technique is used relying on the available discourse and set of examinations on the issue, thus includes secondary sources i.e., governmental published reports and global reports, journals articles, and books.

Following the qualitative approach, the study included the data collection methods by analysing existing information. It further analysed non-numeric data and gathered it in such a way to give insights to generate innovative ideas to help understanding how people experience the world. This approach consists of in-depth knowledge and the analysis of such data entails a large amount of info for a topic to make differences and similarities too, which then helps in deriving meaningful conclusions. As the content analysis of this study brings the best novelty in a study in the concluding paragraph, Modi's realism. Furthermore, existing literature contributed a lot in bringing the best ground-breaking realities in conclusion.

\section{Results and Discussion}

\section{Indian nuclear ambivalence: Past to present leaders}

In terms of nuclear, when one talks about nuclear power ambivalence, the term often glossed in the literature in two forms of dual-use in terms of both technology and formulation, which misleads and transfers attention of operator of technology and those who are managing matters and who are holding it, somewhat to see it as a structural feature on development in themselves.

The reactor was made in order not to foreclose the possibility of building up more weapons in future and thus inaugurated long detailed debate regarding nuclear option and producing it by extension hence galore uncertainty in it. The second round of nuclear tests of India in 1998 was the impossibility of convincing the international community that they had in 1974 when they did peaceful nuclear explosion (PNEs), which was called a demonstration at that time. However, the multiple plausible meaning changed from demo to actionable or practical meaning after testing nuclear device (Abraham 2010).

The adoption of nuclear weapons was acclaimed as the symbol of modern times. Moreover, the speeches of Jawaharlal Nehru (the first Prime Minister of India) also revealed the use of such technology. Though he faces a dilemma about using potential technology for peaceful purposes and expressed that it can ruin or give a progressive contribution to the world, it all lies in on how to use it. He ridiculed the nuclear deterrence idea and in contrast to the instrumental reason that underpinned it, that to set a goal for truth will bring truth and good out of evil ways. Nehru saw the tool as to use for fostering global co-operation but also got feared that it might be able to endanger the state's future. Moreover, India's incapability to restrain the significance of trial of initial stage holds the development of nuclear arms and civil authority from mythic non-alignment and nonviolent co-existence to daily-based threat perceptions.

The shift which began in the 1950s and 1960s had evidence of nuclear program to military modernization (Chacko 2011). India was the first country who laid stress in 1954 for the need for nuclear arms testing and then proposed a non-discriminatory and non-proliferation treaty in 1965, just in initially they 
represented disarmament posture. India's earlier decision regarding its complete nuclear cycle allowed it to capture such capabilities to build for the situation when the geopolitical situation changed. Before testing peaceful tests in 1989, William, the director of the CIA, mentioned that Indian leaders are more interested in thermonuclear weapons ability. Apart from disarmament, the country stated it as they own bomb for national pride but still advocates continuing global disarmament and ending more nuclear testing. They are a member of the International Atomic Energy Agency (IAEA) and have consisted of many warheads but not signed any treaty of CTBT or NPT yet (Bhabha \& Ramanna 2018).

India strongly condemned Nuclear Non-proliferation Treaty (NPT), considering it as a discriminatory measure for the states that do not yet possess the technology. In the period of 1970s to 1980s, India increased delivery system capabilities but tests had been deferred because of pressure from the global community. Although they had domestic pressures for minimal testing from the Indian nationalist party, the PM Narasimha Rao authorized planning in 1995. However, it stopped taking place due to his contradiction about nukes. Then, the next PM, Vajpayee, predicted that it would soon favour a test (Burr 2020). After testing nuclear in 1998, which gave a surprise to the US intelligence community, New Delhi foreshadowed the decision a few years before it by withdrawing from negotiating the endgame of the Comprehensive Test Ban Treaty (CTBT) and that objective, which was passionately championed by the first Prime Minister of India, Jawaharlal Nehru.

CTBT supporters argued that it would help in reducing nuclear shadow over global politics thereby advancing the old goal of nuclear abolition of the state, but did not work. Therefore, the 1974 test was more than a physics experiment. But if there was a juncture in breaking off and liberating from all the restrictions New Delhi faces against its longstanding ambivalence regarding nukes, it was the period to make progress and to avert explosion by permanently ending nuclear tests. India's decision about the test all depends on the party which took office in 1998 and the government of BJP wants to break out of this box. Two senior officials of the party were Atal Bihari Vajpayee and L.K Advani, Prime Minister and Deputy PM, respectively. Bill Clinton's (Former US President) administration made intense efforts to reduce threat dangers after the testing round started by New Delhi. Regarding the signing of CTBT, Vajpayee decided against it which Jaswant Singh expressed as an "irreversible decision" and had been viewed as demonized, unequal side by side as a dangerous treaty (Krepon 2020).

\section{Modi's vision, political leadership \& India's federalism}

Since 2014, in front of state citizens, Modi framed a new sort of engagement with them and for his career's vortex, where he has been sucking everyone in his way. One or mainly his critiques may call him a narcissist for his "self-love", as mentioned in the work of Ramachandra Guha. However, only a few have this view as Modi has courage for what others lacked. He challenged the status quo and claimed himself in pursuit of New India and after the Pulwama-Balakot attacks, he changed the gear and shifted the plot by giving a new theme of Mazboot Neta (powerful leader) to respond to the enemies (Makhopadhyay 2019).

Political analysts describe a threefold vision; getting India into exclusive in trillion of about $\$ 5$ economy clubs, consisting of European Union, Japan, China and the United States of America. They assert themselves to be the forceful nuclear power in the world and lastly to place their utmost Hindu heritage at the centre of their politics (Lefèvre 2020). Moreover, the BJP pledges to make India the sixth-largest economy in the global platform by 2030 . Thus, the second term fully marks a mover toward a nontheocratic Hindu Majoritarianism, as indicated by political analyst, Yogendra Yadav (Dhillon 2019).

The arrival of Narendra Darmodas Modi is a pressing topic; perhaps none frontrunners has gone through much public examination like him. A lot of work has been done on his personality being a leader of Bharatiya Janata Party (BJP), the National Democratic Alliance, and the Prime Minister of the state. Modi's governance style is a matter of deep speculation which is so hard to deny. The remodelling approach and politics of symbolism, as explained by Sen (2016), is a new way of thinking and innovative 
notions in his works that are a part of Modi's political spectrum. Another author, Amarjeet Singh, who also notices about the leader of a state, expressed that various indicators point out Modi's new approaches which are progressive ones.

The high scale of optimism in regards to Modi's social policy that he promoted such as presenting his slogan Sabka Saath, Sabka Vikas (collective efforts, inclusive growth), prompted Mod to mimic the notion which elucidates his undertaking of socio-economic policies, his internationalist orientation to economic policies, and more attempts to bring India's economy into order (Panda 2016). Moreover, he released the manifesto in which he presents a definition for India on the forty-fifth page of the manuscript titled Sankalpil and Sashakht Bharat (determined and strong India) and while declaring it, he further added that nationalism is their inspiration and by 2047, he along with his party, will celebrate complete independence from colonialism.

The manuscript also mentions the objectives of achieving 75 goals by 2022 and transform India from a developing to a developed country. Presiding party's new nationalism embedded in their socio-political agenda Hindutva to demarcate the difference between Deshbakht pro-self-rule and Deshdrohi antinational. His leadership thus focuses on "nation first", which altered the whole Indian Paradigm (Misra 2019).

The defeat of Manmohan Singh in 2014 was the same year as Modi campaigned on the metaphor of being state chowkidar (the night watchman) and to turn the state into the Republic of Jingostan. People appreciated Modi leadership that he deserves more chances for his better performances than the GandhiNehru family who were constrained to country progress for sixty years. Modi's post-victory statements show inconsistency in an ominous warning towards political parties. He shows that in the elections of this year, no party was able to do the garb of secularism to distract people from the right way.

In concerns to his further vision regarding Pakistan in a campaign, he mentioned that the nukes are not for the annual fireworks festival of Diwali (Thakur 2019). Counting two personalities of lived reality and political history, it demonstrates Indira Gandhi's and Modi's leadership that he has been better than her in many aspects. The decisions are taken by him that were not taken by Indira Gandhi during her peak time showing either she would have wanted or not like Modi's abrogation of the special status of Jammu and Kashmir.

The re-election of Modi proved two things; first, that his political leadership had played well politics of the voters and it did not bother anything. Meanwhile, for a couple of years during his time, he had persisted with the worst and reckless thing and that was a profitable demonetization. Thomas Piketty in his book, Capital \& Ideology, mentioned that Disparity is neither Technological nor Economic. He writes that it is all about "ideological and political". Strong leaders thrive in persisting and riding their domineering politics and their ideologies (Gupta 2020). By presenting hyper-nationalistic, Modi focused on national security as the main motive behind election campaigns and his pronouncement to Lok Sabha (governing body in India) which are giving insights into his thoughts and those changes can be taken as sent "signal" to Pakistan.

Modi in this regard left no doubts in his intentions although the issues only concern about the creation of overwhelming qualitative and quantitative edge, the precision-guided missiles base on the land, sea and air (Panag 2019). Modi in the first term of 2014-2019 kept his focus on economic reforms, an image which he maintained irreparably tarnished. According to the national political figures, the rise of Modi however has long been troubled under the indifference of the strike to violence which targeted only the Muslim regions of Gujrat, where he was presented as the leader of the country during his time and now which has long focused on the transformation towards Hindu Nationalism. When he came to power in 2014, some held on to the hopes of his rise, that governments across India would take Modi and his BJP away from this. The factor of Hindu nationalism had animated his rise. 
After securing re-election, he continued leaning his shoulder on that factor as it had played a dominant role in government policy as well as directly threatened state constitutionally mandated secular democracy on the other hand (Bremmer 2019). India represents a unique model of governance of a republic of unitary bias and in the words of Bhimrao Ramji Ambedkar, the Indian jurist, the state is "both unitary and federal as per requirements of time and by circumstances." The course of Citizenship Amendment Act (CAA), the centre-state dispute which Kerala government filed under Article 131 which was accepted by Punjab but was rejected by anti-BJP in the West Bengal to adopt the same course. It gives rights to people that states can express their views although, in the conclusion, they have to abide by the constitution at the finale (Bhushan 2020).

India is widely seen as a federal democracy. However, their recent move to scratch the special status of J\&K by the annulment of Article 370 in their constitution, changes the state into two union territories which received criticism from the state own Supreme Court and International Commission Jurists (ICJ), because the move is not a simple modification in $J \& \mathrm{~K}$ status but a radical transformation. Amendment in the constitution is the basic structure of constitutional draft and that substance even cannot be abrogated by Parliament, to which BJP challenges require amending Indian Federalism Article 368. Thus they made changes by replacing the constituent assembly with legislative assembly by adding Clause 4 into Article 367 to their constitution (Ranjha 2019).

Article 370 annulment wide-opened some suspicions that have long been apparent in the central scheme of the country, where asymmetric negotiations have been made to sort out regional conflicts in India. Some Indian officials called it the root cause for terrorism and declared that those who will support are anti Dallit, anti-women, and anti-tribal. From the period 1989-2014, regionalisation contributed to deeper federalism along with rising regional autonomy vis-à-vis the central government was an almost inexorable procedure by which the BJP altered trajectory when they came to power of political domination. Alfred Stephan, a political scientist, identified that the federal system can be almost like constraining demos but in conclusion, the spectrum federalism serves to undermine power consolidation through state preponderances (Tillin 2019).

\section{Rise of realist thinking: Reflection from Nehru to present era}

International relations attempts have often made to counter the 'hegemonising' influence of realism, particularly in India's milieu, and in this context, full-spectrum realist thinking needs to be engaged. Scholarly studies of Indian realists used neo and classical realism lenses to make a better understanding of Indian engagement as the work of C. Raja Mohan demonstrates this engagement with history. Meanwhile, some also challenge the assertion of morality as the main pillar in the state independent foreign policy as the claim by Bharat Karnad shows that Mohandas Karamchand Gandhi assertion of non-violence was strategic and in various candid moments, he revealed the true self which shows the eventually run of realist postures.

One's national interest is advanced by presenting an aggressive use of morality for this purpose and the term moralpolitik has been used to signify that. Moreover, India's policy is non-alignment and not based on morality but fully grounded on state interest calculations according to Krishnaswamy Subrahmanyam (1998). To further advance military capabilities in terms of seeking to gain ascendency in the region or for power balancing logic in the region and other powers out of it, the picture is created that the republic of India is not being as an outlier in state behaviour (Roy 2018).

Nehru understanding of the world went through multiple phases and of which idealism is a strong component of his worldview. A nationalistic point of view believed that India was destined to play a great role in the global arena. Before independence, Nehru even marked that it would be the sixthlargest power in the futuristic world order after Russia, China, America, Japan, and Europe. Power maximization and shaping world order were quite dominant to Nehru's worldview (Mohan 2014). 


\section{Nuclear arms decision making: Civil-Military relations in India}

Ordering of civil-military relations both lies in the national security framework and the conflict between them may not be visible or manifested forever but an underlying theme of past times of politics and militaries (Shukla 2012). In the public domain, there is little information about the $\mathrm{C} 2$ of nukes in India which is not surprising for having less knowledge about it. One of the political scientists, Vipin Narang, argues that the surrounding opacity level is extraordinary in their nuclear posture and senior civilian official, officers, and scientists have a stronghold on Strategic Forces Command. In 2003, the government declared a two-layered structure Nuclear Command Authority (NCA) under the chairmanship of the Prime Minister consisting of the Political Council and the other Executive Council chaired by NCA to the Prime Minister and made a statement regarding the authority of the sole body about the use of nuclear weapons. Another perceived challenge rose about controlling such weapons and whether the military would end up controlling and making decisions. However, historical evidence all shows that till 1998 and even much later, the military has no role in making decisions. The military scientist, Gaurav, stated about military lack of awareness about the weapons they have, the numbers that have never been told, and how would they be employed on the battlefield.

Despite many challenges which the Draft Nuclear Doctrine (DND) holds stipulations, the government of India has to keep on projecting those policies as declared in Cabinet Committee on Security (CCS) by reviewing the prevailing command and control (C2) structure. They operate new techniques and target retaliatory attacks. Many other things prove about the organizational barriers and ongoing rivalries between civil and military. The evolution of India's posture is still almost driven by technical bureaucracies, scientists, specifically civilian political leadership of the PM office (Ramana 2019).

The dysfunctional civil-military relation is another path for nuclear conventionality in India, apart from cultural and other normative reasons, and represents a deep-seated transformation in their relations where martial required some substantive ways in nuclear policies. Distrust of civilian on military for the young democracy is normal that wet behind ears after the relating example of a book authored by Samuel Finer titled 'Man on the Horseback'. India's civilian leadership determined on the point to ensure that foreign policy of their country did not over militarised. Undoubtedly, India's civil and other scientists along with bureaucrats all favour nuclear weapons, but not like Soviet-US models where the operational drivers of military government had caused the irresponsible spreading of arsenals. Civilian leaders allowed the military to complete operational autonomy in conventional times. In sum, they made the military their partners in all quelling and domestic insurgencies. Furthermore, there was military aid to a civilian in twenty century where the military waged 12 campaigns out of 17 , so the results do not present only distrust issue.

Post-1998 changes occurred when state leader decided to construct more active nuclear arsenals, but they exposed minute hesitancy in the institutionalising military role while planning. The government also created staff namely Integrated Defence Staff (IDS) to make dual preparation and coordination in equipped forces. Over the last few years, political interference increased in the PMO who have asserted authority in armed and systematic agents by creating institutions to cope with all matters of decision making and related to other everlasting planning. The finest example of it is the establishment of Strategic Planning Staff (SPS) which accomplishes few long-term arrangements for Strategic Forces Command (SFC). With the establishment of such organizations, civilians decision-makers of India has made the armed contribution in particular planning to nuclear though having dominated nuclear arrangement very early (Kampani 2019).

Except that the civil-military relations in the space domain are moving from India Space Research Program (ISRO's) space launchers program to Defence Research and Development Organization (DRDO'S). All of it shows that India is advancing its military by inducting new defence technologies as well as doctrines. This indicates a clear paradigm shift but analysts argue that present civil and military integration is impossible yet and not yet taking place in India's perspective. But then again, external 
expert observations state that separation of both of them in regards to space programs is not possible (Paracha 2013). Relation between politicians and bureaucracies combined while the military has always been uneasy at its best, and all their increasing civil control has been a continual source of resistance and frustration for the military because of the adjustments made by political leaders by dropping the rank of high-ranking officers and giving the right to Ministry of Defence (Hooda 2018).

The creation of this armed police force may look like the rival army, thus army feels obliged to carry big play cards to make a distinction between them and others and all CMR dissonance, as well as the acrimony of MoD which does not bode well for its functioning, contributed into the dissatisfaction of military (Retd 2018). In shaping India's determining roles, Prime Minister's role is important in nuclear matters and Modi revisiting of No First Use though it has not altered yet. Overall, debates on changing posture towards first use are marked one thing, that is nuclear weapons as a political instrument rather than a military instrument that could be used as a war-fighting tool (Mishra 2019).

\section{Indian policy towards Pakistan: Political philosophy, propaganda, and saffron terrorism}

India's doctrinal shifts are not secret, which their Defence Minister himself mentioned that transfer of No First Use towards First Use rest if things depend upon future circumstances. However, the shift has implications for strategic peers, specifically Pakistan. Although it is not new, they argued much before their policy of No First Use (NFU) is not permanent and can change when needed as cold start doctrine, surgical strikes, and proactive military new strategies all show the shift. But the change depicts a target to acquire both hard and soft nuclear power capabilities. Then again, all counterforce capabilities do not alarm, but the thing to ponder is that they all are under Rogue Hindutva Regime though the command lies under the sole body of NCA chaired by Modi.

The international community ignores the repercussions of right-wing extremists' control over nuclear weapons. The repetition of the same words in election campaigns says we have a nuclear button and more into it about drum beating to stir up the separatist base. Many foreign nuclear experts ignored the irresponsible statements made by Modi during their election campaigns but Pakistan's PM Imran Khan expressed his concerns under the Modi regime over nuclear arsenals. India released another threat for Pakistan by mentioning the commitment and depends on futuristic situations before it deployed nuclearcapable delivery vehicles.

Intentions unveil military outbreak in the neighbouring country of Pakistan to distract global community attention as an abrogation of Article 370. Illegal annexation is their proofs which in return also boosting them to be ready for responding to India's military misadventures but it shows a scary reality under RSS cohorts and BJP of Modi (Jaspal 2019). Modi's BJP which claims over the autonomy of Indianadministered Kashmir has hindered growth while nurturing the area of smuggling and thriving terrorism. Regarding the unprecedented lockdown faced by people, experts analysed that move to tether the Muslim majority is a gamble but the game is different so that it could trigger conflict with Pakistan.

Modi focus on Hindutva is interpreted as "Hinduness" by reframing it as their identity rather than religion or divinity all relate to the history of the time of aroused tensions between both Muslims and Hindus. Different tactics for fostering Hindu nationalism includes anti-Muslim rhetoric's, falsely lynching of Muslims by accusing them of eating beef and accusing men of changing demographics by seducing Hindu women's, where all tactics were applied to expand their notion. Airstrikes by both sides and all depict that threatens to reignite the conflict between them alerting the whole world that they might go for the nuclear option.

The global community cooled down the situation by pulling them back from the war brink, although Modi still tries to re-form India on BJP's Hindutva image (Yusuf 2019). The by-product of Hindutva termed saffron terrorism which can define as the use of unintended forces by organizations associated with Sangh Parivar of Savarkar, Monjee, and Golwalker, the creator of religious-political dogmas and 
all that extensively focuses on terrorist dogmas of Islamist variations of fierce extremism, as it had evolved seven incidents in 2004-2008 in-between period. Bal Thackery, the founder of Shiv Sena, stated about the rise of Islamic terrorism and its growth which for them Hindutva is the only way to counter, as their ideology vividly reflects the dream for Akhand Bharat, the RSS production (Iqbal 2020).

India has undergone a rapid transformation from a secular state to a fascist or saffron seed state under the regime of Modi. The term Saffronisation (Indian political neologism, a term which changed after saffron robes by Hindu sanyasis) associates with saffron terror used to describe the militarized acts of Hindu nationalism to recall and glorify the ancient history of Hindus. Different ways of protection in the name of "Gau Raksha" (protection of cow) by the right-wing pro-Hindutva, emboldened by state groups, the saffron terror uses such tactics and is applied on Muslims by lynching them publicly. These saffron ideologues are indicating "Murder of History" for Indian polity. However, being poisoned by saffron masters that Muslims are the real cause as argued by Hindus are wrong (Syed 2019).

Pakistan reserved its full rights to use all those options for national security and socio-political (ideological) interests so India does not take Pakistan's nuclear capabilities so light, as stated by a retired army officer, Gen Khalid. He further added that they must have the responsibility to maintain nuclear as well as strategic balance in the conventional equation in regards to India. Strategic instability would lead both states towards catastrophic consequences in case of the introduction of unbalancing by either party (Salam \& Shah 2020). Modi marginalises the Muslim minority in different ways, including the decision to the illegal annexation of Kashmir, discrimination through citizenship law, and building up a temple on the site of the former Babri Mosque.

Couples of decisions and the targeting of Azad Kashmir lead to the increase of nuclear-armed tensions between both states (Kidwai 2020). Modi's rule may hinder the openness, secularisation, and deep sense of lack of trust in both states and the hostility between them can be sensed on social media. As his strengths are linked to the very prominent goals of nationalism, Hinduism revives along with its populism (Gang 2019). By true means, Modi has come out for war-mongering once more time within ten days, enough to crush Pakistani armies in the event of a future conflict situation.

In addition, air and surgical strikes have been carried out by New Delhi to beat the militant camps inside the Republic of Pakistan. However, after tit for tat strikes, both once again on the verge of war in 2019. However, the re-election has been again undermining the secular character and taking serious actions which have threatened to deepen sectarian separation and the amendment in citizenship law (CAA) received criticism for the attitude of discrimination towards Muslims (the largest minority). An attempt made by a prior volunteer of Hindu extremist of Rashtriya Swayamsevak Sangh (RSS) to side-line the Muslims. India is planning to carry out a bloodbath in the $74^{\text {th }}$ speech at the UN. Imran Khan warned and after get verified, it was the time for a revolution of information.

RSS ideology is about racial purity and superiority and mainly of Hindu race over other religions as they express that Hindutva is not Hinduism but Hindudom (spheres of Hindus). Savarkar motto thus states their thoughts, "Hinduizing all politics and militarizing Hindudom". RSS inspired India that in all their endeavours the world has nothing to do, so in this regard, India will invade Pakistan, Bangladesh, Nepal, and Sri Lanka to make their dream of Greater India comes true. Pakistan in response to them keep on trying to mobilize global community concerns over the issue which is increasing day by day as the adversary state gets bolder (Oruç 2019).

Deliberative ideology is a normative ideal but in the case of India still, much maturity left to learn. What emerges in India more seems like their preferences over us vs them. As Vinayak Damodar Savarkar argued, if Muslims and Christians are born in India, even in that case, they could not claim ownership. All the qualities of Hindutva are essential to have a common race, common nation, and common civilization (Jati, Rashtra and Sanskriti). BJP and RSS both thus have vowed to create a "Hindu Nation" by making differences that Hindus do not need to prove them as Hindu is Indian by default but not 
Muslims (Prasanna 2020). India has managed to promote Hindi culture by applying its strategy of soft power in order to attract a global audience for the expansion of their culture.

Therefore, all attempts depict dangerous things to come as Shiva Sena's attitude towards Muslims artists in India, BJP that faithfully follows the philosophy of Hindutva, and continuity in following the RSS philosophy. Strategic and commercial interests in the South Asian region, mainly their discriminatory attitudes, dehumanised policies in India, and violence in Kashmir without realising the attitude in return and its consequences, unmitigated hostile behaviour towards Pakistan mainly their refusal to initiate any dialogue and the refusal of past animosities. All factors push towards perennial instability of South Asia, not only for Pakistan (Ashraf 2019).

The rise of Hindu nationalism and the prominence of BJP have profound ramifications for its relationship with the neighbouring nuclear state of Pakistan. This is evident from the hard-line approach they are taking, especially in terms of security, particularly when it relates to Pakistan and Muslims as well for the reason that invites the likelihood of conflict between both states. As they know, both states have the abilities to retaliate and the stance appears over the second strike shifting now under the ruling party of BJP. Claims for first-strikes are clearly defined as it will depend upon another side in case of initiation and the rise of new ideology also raises concerns for relations between the two countries. Their different slogans seem like tactical support for Hindu nationalists for their approaches towards Pakistan. As the dynamics change, Pakistan's founder Muhammad Ali Jinnah's doubts seem to be right about Nehru's views that India could be peaceful and multi-religious (Malji 2020).

\section{Conclusion}

In India's leadership context, Modi's sense of realism is far high in comparison to others which are maybe taken from predecessors to some extent. In addition, situational and contingency theory is best in this regard to relate with him for the reason of core principle that lies in it, where some leaders bring changes in their behaviours in accordance to the situation, while some follow the old beliefs and continue them despite training. India's leadership preferences show more support for jugaad and pragmatism rather than going for balancing phenomenon. In comparison to predecessors, Modi's let it be style and his rejection of normative aversion towards Nuclearization expresses the difference from the predecessors. Although Nehru proclaimed for use of technology, however, BJP's hard and aggressive stance brought a different look after coming to power. Modi geared up realist norms because before the Modi regime, there was undoubtedly fluctuations and ambivalence about some decisions like the signing of NPT and military modernisation. Modi's journey towards making Greater India and achieving goals through a materialistic mind shows a new picture that others may not ponder.

Adoption of new approaches is a matter of intense speculation, the ideological framework, revision of NFU. Furthermore, giving up special intentions towards nukes are raising serious concerns for Pakistan. Annulment of Article 370, CAA, and state-centric policies show more similarities with Kautilyan thoughts. Now the replacing of Kautilya's preaching, such radical shifts of Howdy Modi shows indication of steps for taking a higher level of risks. On the other hand, all these factors contributed to the rise of the BJP as well. Such interference as rogue Hindutva holds on military matters is alarming for Pakistan because nukes are political tools. As new tactics, applied agendas also target Muslim minorities in order to challenge the regional stability through waging different propagandas. Such hard-line approaches, hostile attitudes, discriminatory response towards Muslims, and new policies could result in a nuclear holocaust. One-sided support of the US for such Hindu-nationalist tactics shows a matter of serious concerns for Pakistan that may bring unexpected results in the case of any escalation because Pakistan, on the other hand, has been also preparing for a retaliatory response that shows its readiness for any conflicting situation. 


\section{References}

Abraham I (2010) 'Who's next?' Nuclear ambivalence and the contradictions of non-proliferation policy. Economic and Political Weekly 45 (43):48-56. https://www.jstor.org/stable/20787501.

Ashraf MM (2019) The BJP's politics. International The News, 10 January. [Accessed 01 Feb 2021]. https://www.thenews.com.pk/print/416766-n-a.

Bhabha HJ \& Ramanna R (2018) Indian nuclear program. [Accessed 10 March 2019]. https://www. atomicheritage.org/history/indian-nuclear-program.

Bhushan R (2020) CAA-inspired politics puts India's federalism under stress. Cnbctv18.Com, 22 January. [Accessed 10 June 2020]. https://www.cnbctv18.com/views/caa-inspired-politics-putsindias-federalism-under-stress-5107481.htm.

Bremmer I (2019) Modi was India's best hope for economic reform, things have changed. Time, 20 December. [Accessed 10 June 2020]. https://time.com/5753624/india-narendra-modi-nationalism/.

Burr W (2020) The Clinton administration and the Indian nuclear test that did not happen - 1995-1996. Wilson Center, 9 May. [Accessed 08 May 2020]. https://www.wilsoncenter.org/publication/theclinton-administration-and-the-indian-nuclear-test-did-not-happen-1995-1996.

Chacko P (2011) The search for a scientific temper: Nuclear technology and the ambivalence of India's postcolonial modernity. Review of International Studies 37 (1):185-208. https://doi.org/10.1017/ S026021051000046X.

Dhillon A (2019) Analysis: Economy, Hindu-first impact are Modi's challenges. AP NEWS, 24 May. [Accessed 16 April 2020]. https://apnews.com/6254c3a4e5fb4b27b7334da80c45e6ec.

Gang D (2019) Pros and cons of Modi as a strong politician. Global Times, 29 May. [Accessed 29 March 2020]. https://www.globaltimes.cn/content/1152199.shtml.

Gupta S (2020) Why Modi proves strong leaders don't always bother about good economics. ThePrint, 7 March. [Accessed 16 March 2020]. https://theprint.in/national-interest/why-modi-proves-strongleaders-dont-always-bother-about-good-economics/377106/.

Hashmi SMA, Hashmi DAS, \& Farooqi J (2018) Use of soft power by India as a strategic weapon: Media's manipulation. NDU JOURNAL 32 (1):1-16. https://ndu.edu.pk/ndu-journal/2018.php.

Iqbal DK (2020) The rise of Hindutva, saffron terrorism and South Asian regional security. Journal of Security and Strategic Analyses; Islamabad 5 (1):43-63.

Jaspal DZ (2019) Nuclear weapons under Hindu supremacist Modi Govt—Dr Zafar Nawaz Jaspal. Global Village Space, 3 September. [Accessed 25 March 2020]. https://www.globalvillagespace. com/nuclear-weapons-under-hindu-supremacist-modi-govt-dr-zafar-nawaz-jaspal/.

Kampani G (2019) Why India's post-1998 evolution as a conventional nuclear weapons power evokes surprise. Journal for Peace and Nuclear Disarmament 2 (1):170-183. https://doi.org/10.1080/257 51654.2019 .1620434$.

Khan Z (2020) Conceptualizing India's evolving nuclear strategy under the essentials of minimum deterrence: Limitations and challenges. Comparative Strategy 39 (6):579-591.

Kidwai K (2020) Keynote address and discussion session with Lieutenant General (Retd) Khalid Kidwai. IISS, 6 February. [Accessed 17 February 2020]. https://www.iiss.org/events/2020/02/7th-iiss-andciss-south-asian-strategic-stability-workshop.

Krepon M (n.d.) Looking Back: The 1998 Indian and Pakistani nuclear tests. Arms Control Association. [Accessed 8 May 2020]. https://www.armscontrol.org/act/2008-06/looking-back-1998-indianpakistani-nuclear-tests?print $=$.

Lefèvre C (2020) Heritage politics and policies in Hindu Rashtra. South Asia Multidisciplinary Academic Journal 24/25. https://doi.org/10.4000/samaj.6728.

Makhopadhyay N (2019) Narendra Modi: View: Has Modi evolved from being a strong leader to a crafty one as well? The Economic Times, 23 May. [Accessed 10 March 2020]. https://webcache. googleusercontent.com/search?q=cache:HDNHfi73Nz4J:https:/economictimes.indiatimes.com/ news/elections/lok-sabha/india/view-has-modi-evolved-from-being-a-strong-leader-to-a-craftyone-as-well/articleshow/69449857.cms $+\& \mathrm{~cd}=1 \& \mathrm{hl}=\mathrm{en} \& \mathrm{ct}=\mathrm{clnk} \& \mathrm{gl}=\mathrm{pk}$.

Malji A (2020) The rise of Hindu nationalism. Education About Asia 23 (1):39-43. 
Mishra S (2019) Revision of India's nuclear doctrine: Repercussions on South Asian crisis stability. Journal of Indo-Pacific Affairs Winter: 88-106.

Misra S (2019) BJP manifesto outlines Modi's vision of Indian nation. ORF, 10 April. [Accessed 07 April 2020]. https://www.orfonline.org/expert-speak/bjp-manifesto-outlines-modis-vision-of-indiannation-49798/.

Mohan CR (2014) Nehru's realism. ORF, 10 November. [Accessed 10 March 2020]. https://www. orfonline.org/research/nehrus-realism/.

Newmann B (2020) A brief introduction to theories on international relations and foreign policy. [Accessed 8 June 2021]. http://www.people.vcu.edu/ wnewmann/468theory.htm.

Hooda DS (2018) Opinion | Need to review civil-military relations, writes Lt Gen DS Hooda after row over defence spokesperson's tweet. News18, 30 October. [Accessed 04 June 2020]. https://www. news18.com/news/opinion/need-to-review-civil-military-relations-writes-lt-gen-ds-hooda-afterrow-over-defence-spokespersons-tweet-1924035.html.

Oruç MŞ (2019) What is Hindutva and will it cause another war in South Asia? Daily Sabah, 01 October. [Accessed 10 June 2020]. https://www.dailysabah.com/columns/merve-sebnem-oruc/2019/10/02/ what-is-hindutva-and-will-it-cause-another-war-in-south-asia.

Panag LGHS (2019) In his hyper-nationalistic election speeches, Narendra Modi is writing India's security doctrine. ThePrint, 2 May. [Accessed 10 May 2020]. https://theprint.in/opinion/in-his-hypernationalistic-election-speeches-narendra-modi-is-writing-indias-security-doctrine/229937/.

Panda JP (2016) Narendra Modi and his model of governance. Journal of Asian Public Policy 9 (2):9597. https://doi.org/10.1080/17516234.2016.1165444.

Paracha S (2013) Military dimensions of the Indian space program. Astropolitics 11 (3):156-186. https:// www.tandfonline.com/doi/full/10.1080/14777622.2013.842453?scroll=top\&needAccess=true.

Prasanna S (2020) Is India's BJP government set to create a 'Hindu Pakistan'? The Diplomat, 16 January. [Accessed 06 September 2020]. https://thediplomat.com/2020/01/is-indias-bjp-government-setto-create-a-hindu-pakistan/.

Ramana MV \& Borja LJ (2019) Command and control of nuclear weapons in India. NAPSNet Special Reports, 01 August. [Accessed 10 May 2020]. https://nautilus.org/napsnet/napsnet-special-reports/ command-and-control-of-nuclear-weapons-in-india/.

Ranjha ZU (2019) How BJP is destroying India's constitution and federalism. The Friday Times, 30 August. [Accessed 08 May 2020]. https://www.thefridaytimes.com/how-bjp-is-destroyingindias-constitution-and-federalism/.

Retd AAP (2018) There is growing civil-military dissonance and acrimony in India's defence ministry. ThePrint, 30 October. [Accessed 10 May 2020]. https://theprint.in/opinion/there-is-growing-civilmilitary-dissonance-and-acrimony-in-indias-defence-ministry/141359/.

Roy N (2018) Realism in the study of international relations in India. ORF Issue Brief September (253):1-8.

Salam HA \& Shah MA (2020) Lt Gen (r) Kidwai warns India not to take Pakistan's nuclear capability as a 'bluff'. International The News, 24 April. [Accessed 10 June 2020]. https://www.thenews. com.pk/latest/610366-lt-gen-r-kidwai-warns-india-not-to-take-pakistans-nuclear-capability-as-abluff.

Sen R (2016) Narendra Modi's makeover and the politics of symbolism. Journal of Asian Public Policy 9 (2):98-111. https://doi.org/10.1080/17516234.2016.1165248.

Shukla R (2012) Civil Military Relations in India. New Delhi: Centre for Land Warfare Studies.

Subrahmanyam K (1988) Indo-Pak nuclear stand-off: A challenge and an opportunity. The Times of India, 6 June, 1.

Syed AR (2019) Saffronised India. Daily Times, 26 July. [Accessed 10 April 2020]. https://dailytimes. com.pk/437525/saffronised-india/.

Thakur R (2019) Can Narendra Modi transform India? [Accessed 12 June 2021]. https://asialink.unimelb. edu.au/asialink-dialogues-and-applied-research/commentary-and-analysis/can-narendra-moditransform-india.

Tillin L (2019) The fragility of India's federalism. The Hindu, 08 August. [Accessed 09 June 2020]. https://www.thehindu.com/opinion/lead/the-fragility-of-indias-federalism/article28872165.ece. 
Tripathi S, Prabhakar GP, \& Liddle J (2015) Leadership insights from the top: Exploring leadership through the narratives of CEOs in India. International Journal of Public Leadership 11:126-146. https://doi.org/10.1108/IJPL-02-2015-0006.

Umar S (2020) Level of analysis (easy explaination). [Accessed 24 April 2021]. https://www.academia. edu/2508137/Level_Of_Analysis_Easy_Explaination_.

Yusuf A (2019) Kashmir: How Modi's aggressive 'Hindutva' project has brought India and Pakistan to the brink - again. The Conversation, 5 September. [Accessed 03 June 2020]. http://theconversation. $\mathrm{com} /$ kashmir-how-modis-aggressive-hindutva-project-has-brought-india-and-pakistan-to-thebrink-again-122851. 